\author{
Review Article
}

\title{
FIVE COMMON RIGHTS ON AYURVEDIC DIETETICS - A REVIEW
}

\section{Chiranjit Biswas ${ }^{1 *}$, Supriyo Chaudhuri²}

${ }^{*}$ Lecturer, ${ }^{2}$ Reader, Department of Sanskrit Samhita \& Siddhanta, J.B. Roy State Ayurvedic Medical College \& Hospital, Raja Dinendra Street, Kolkata, India.

\begin{tabular}{l}
\hline Article info \\
\hline Article History: \\
Received: $29-11-2021$ \\
Revised: $20-12-2021$ \\
Accepted: 04-01-2022 \\
\hline KEYWORDS: \\
Ahara Vidhi, \\
Ayurvedic Dietetics, \\
Ahar Upachar, \\
Ayurvedic Food \\
concept, Poshan.
\end{tabular}

\section{INTRODUCTION}

Food may be described as any substance containing nutrients that can be ingested by a living being and metabolized into energy and body tissue or simply it called as any substance consumed to provide nutrition support for an organism. In Ayurveda, literally Ahara demonstrated as anything which is consumed through mouth is called Ahara.[1] Every possible things which is responsible for the formation of body, maintain the body as well as creator of the disease in the body is termed as Ahara. Ahara is the fundamentals of origin and subsequent maintenance of our body[2]. Preferably consumption of Hita Ahara provides happiness and Ahita Ahara is meant for unhappiness. ${ }^{[3]}$ In another context to sustain our life Anna or Ahara is the best to consume ${ }^{[4]}$ as because it not possible to make a disease free life devoid of proper diet and diet is mentioned as unparalleled rather the medicine. ${ }^{[5]}$

\begin{tabular}{|l|l|}
\hline \multicolumn{3}{|c|}{ Access this article online } \\
\hline Quick Response Code & \\
\hline https://doi.org/10.47070/ijapr.v10i1.2193 \\
\hline $\begin{array}{l}\text { Published by Mahadev Publications (Regd.) } \\
\text { publication licensed under a Creative } \\
\text { Commons Attribution-NonCommercial- } \\
\text { ShareAlike 4.0 International (CC BY-NC-SA 4.0) }\end{array}$
\end{tabular}

\section{MATERIALS AND METHODS}

The ancient Ayurvedic literatures were looked into in search of the concepts of Ayurvedic Dietetics. The online search engines i.e. Google Search and PubMed Database and others were searched with the headings, Ayurvedic Dietetics in Ayurveda, relation of Ahara and others. The obtained information were collected and interpreted accordingly.

\section{Right Quantity (Ahara Matra)}

Devour in right amount and the quantity of food to be taken relies upon the energy of Agni. The amount of food which, without annoying the equilibrium of Dosas and Dhatus of the body and receives digested further to metabolized in right time, is to be appeared because the proper quantity.[6] Percept of practicing for taking meals, the stomach capability ought to divided into three additives, one element must be crammed up through solid food the second one aspect want to be filled up via liquid and remnant element need to be left for Vata Pitta and Kapha. With due regard to this precept does now not fall a sufferer to any of the damaging consequences which concern with Ahara Matra. ${ }^{[7]}$ The right quantity of food does not depend upon the individual of the food articles. If the food article is heavy simplest three fourth or half of the stomach potential is to be filled up. Even in the case of mild meals articles excessive intake isn't conductive to the safety of the power of digestion and metabolism.[6] The Laghu Ahara or mild food 
articles like Sali (Oryza sativa Linn), Swastika (a variety of Oryza sativa Linn), Mudga (Phaseolous mango Linn), common Quail, gray Partrige, Antelop, rabbit, wapiti, Indian Sambar, etc.,[6] are predominant within the functions of Vayu and Agni and the Guru Ahara or heavy ones like preparations of flour, sugarcane and milk, Tila (Sesanum indicum Linn), Masa (Phaseolous radiates Linn) and meats of marshy and aquatic animals in Prithvi and Apa Mahabhutas. [6] Consequently, according to their traits, the mild articles of food, being stimulants of urge for food and by using nature are considered to be a great deal less harmful even though taken in more of the prescribed amount. Alternatively, heavy articles of meals, being with the useful resource of nature, suppressors' appetite are incredibly dangerous if taken in excess except there is strong power of digestion and metabolism completed via bodily exercising. Therefore the amount of meals is to be considered depending upon the status of $A g n i^{[6]}$ and should practice to take food not in less quantity, not in large quantity but in proper quantity, because the less quantity of food is the cause of Karshya Roga ${ }^{[4]}$ and lack of happiness and loss of strength ${ }^{[8]}$. On the other hand large quantity food causes Alasya or lassitude, Gurutwa or feeling of heaviness and Atopa or gargling noise inside the abdomen and debility.[8] Avoidable practice also includes Samasana or mixing healthy and unhealthy foods together, Adhyasana or taking food over the previous food is digested properly. ${ }^{[9]}$

Therefore, appropriate quantity of food should be partaken always and that certainly helps in bringing about strength, complexion, happiness and longevity without disturbing the equilibrium of Dhatus and Dosas of the body. [6]

\section{Right Time (Ahara Kala)}

Dual context has been designated in the view of Kala by pertaining with daily and seasonal diets and regimes concerning wholesomeness of Ahara and specific states of individual in relation to health and age.[10] To obtain ultimate happiness of life Ahara is considered to be consumed once in a day and should be habituated with fillings of hunger justified with proper digestion of previous meal.[4] Practice of partaking food either before or prolonging time as well as neither in adequate nor in excessive quantity should avoid for restoring the normal health. Habituated with earlier than the standard time of partaking meal causes many ailment even loss of life; after the lapse of common time his digestive energy gets stricken by $V a y u$, the food get digested with trouble and the person does not choice to partake the second meal.[8] With due consideration of Dosha Pravritti to the daily and seasonal diets are furnished in Table 1.

Table 1: Dosha Pravritti to the daily and seasonal diets ${ }^{[11]}$

\begin{tabular}{|c|c|c|c|}
\hline Season & Doshik Condition & Suitable Rasa & Suitable Foods \\
\hline Sisir & Kapha Chaya & Snigdha, Amla, Lavan & $\begin{array}{l}\text { Fatty Flesh of Udaka \& Anupa Desha } \\
\text { Velasaya Mamsa } \\
\text { Madira and Sidhu with Honey } \\
\text { Godugdha, } \\
\text { Ikshu Vikriti } \\
\text { Taila } \\
\text { Nava Odana } \\
\text { Hot water }\end{array}$ \\
\hline Vasanta & Kapha Prokopa & Laghu, Kashyay, Katu, Tikta & $\begin{array}{l}\text { Yava \& Godhuma (wheat) } \\
\text { Sarabha, Sasak, Ena, Lava, Kapinjala Mamsa } \\
\text { Sidhu \& Mridvika }\end{array}$ \\
\hline Grishma & Vata Chaya & $\begin{array}{l}\text { Madhur, Sita, Drava, } \\
\text { Snigdha }\end{array}$ & $\begin{array}{l}\text { Sali } \\
\text { Jangal Mriga \& Pakshi Mamsa } \\
\text { Ghrita Dugdha } \\
\text { Plenty of water }\end{array}$ \\
\hline Varsha & $\begin{array}{l}\text { Pitta Chaya \& Vata } \\
\text { Prokopa }\end{array}$ & Madhur, Snigdha & $\begin{array}{l}\text { Old Yava, Godhuma, Sali } \\
\text { Jangal mamsa, Majja with Jusa } \\
\text { Mridvik or Arista } \\
\text { Boiled and cooled water with Honey }\end{array}$ \\
\hline Sarat & $\begin{array}{l}\text { Pitta Prokapa \& } \\
\text { Vata Prasama }\end{array}$ & Madhur, Laghu, Sita, Tikta & $\begin{array}{l}\text { Sali, Yava, Godhuma } \\
\text { Mamsa of Lava, Kapinjala, Urabhra (sheep), } \\
\text { Sarva, Sasak }\end{array}$ \\
\hline
\end{tabular}




\begin{tabular}{|l|l|l|l|}
\hline & & & $\begin{array}{l}\text { Ghrita admixture with Tikta Oushadha } \\
\text { Water: Hamsodoka }\end{array}$ \\
\hline Hemanta & Pitta Prasama & Madhur, Amla, Lavan, Ushna & As Prescribed in Sisir \\
\hline
\end{tabular}

The period for digestion of food and medicines requires four Yama or twelve hours and two Yama or six hours respectively. It may be earlier or delayed depending upon the power of Agni.[12] Related practice of partaking diet in seasonal context it is advised to take food in the morning wherein the nights are too lengthy (Hemanta and Sisir Ritu) in traits contrary of the qualities of season. In Grishma and Pravrit Season wherein days are very lengthy, meals within the afternoon is appropriate and in Sarat and Vasanta wherein day and night are equal meals prefers to partake in the middle of the day or dividing in day and night equally.[13] To maintain the disease free condition it is also to be mentioned that the closing eight days of Kartika Masa or third week of November and first eight days of Agrahayana or fourth week of November are called Yamadramstra Kala. All through this era one can be healthful if he is taking handiest small amount of food [14] and the closing and first seven days of the every Ritu (preceding and following) are collectively called as Ritusandhi Kala.[15] In the course of this period the regimens of the previous season have to be discontinued steadily and those of the succeeding season followed slowly. If then again, they may be discontinued or adopted, disease due to Asatmya develops.[16]

\section{Right Quality (Rashi or Ahara Guna)}

The quality of food depends upon the variations in different aspect as per classics. According to source Sthavara or vegetable products and Jangam or animal products, according to Desha, Anupa Desha and Jangal Desha and Sadharana Desha, according to Prabhava, Hita or wholesome and Ahita or unwholesome, according to Mahabhuta, Kshiti, Apa, Teja, Maruta, Bom, according to Rasa, Madhur, Amla, Lavan, Katu, Tikta, Kashyaya and according to nature of intake, Ashitam or eatables, Khaditam or chewable, Pitam or drinkable, Liram or likeable and according to Virya, Sita \& Ushna food are been classified.[17] Food should be specially processed well for health endowed with desired taste, etc. pleasing to mind, clean, not very hot, and freshly prepared.[18] Exclusive forms of meals are described which will cope with the twelve extraordinary sorts of food and drink. They are mentioned as Sita (cold), Ushna (hot), Snigdha (demulcent), Rukshya (no demulcent), Drava (liquid), Shuska (dry), Ekakalika (taken once a day), Dwikalika (twice a day), Oushadhayukta (all in favour of medicinal drug), Matrahina (taken in smaller quantity), Dosa Prasamana (taken for the pacification of any irritated Dosa and brought for subsistence. [19] Sita or Cold food and drink is advised in the conditions of Trishna (thirst), Ushna (heat), Mada (alcoholism), Daha (burning sensation), Raktapitta, Visa (poisoning) and Murccha (epileptic fits) as well as those suffering from the effects of excessive sexual activities.

1. Ushna or warm food and drinks is advised while affliction with the aggravation of bodily Kapha and Vayu as well as those already treated with purgatives of Sneha and Aklinnakaya by full of Kleda.

2. Snigdha food and drink is advised in such a condition of aggravation of Vayu and from a Ruksa condition of the body as well as those suffering from the effects of excessive Vyabaya and those accustomed to physical exercise.

3. Ruksa (or no demulcent) food and drink is advised while with an excess of bodily Medas and Kapha as well as those suffering from Meha and those previously treated with a Sneha should be treated with Rukshya Dravya.

4. Drava (liquid) food is advised in weak, parched and thirsty persons should be given, while those suffering from Meha and ulcers.

5. Dry (non-juicy) food is advised whenever bodies are full of Kleda (bodily moisture) should be given

6. Ekakalika or Only one meal every day is advised with impaired digestions, so that the digestive fire may have opportunities should to be rekindled;

7. Dwikalika or Two meals a day while persons with proper amount of digestion should be given.

8. Oushadha Yukta or medicine should be given with food and drink to a person averse to it

9. Hinamatra or Smaller quantity while food and drink in should be beneficial to persons suffering from impaired digestion or any other disease.

10. Dosa-Prasamana food and drink is administered with due regard to the bodily Dosa.

11. Vrityartha food and drink while any kind of food and drink taken for the preservation of life by a healthy person would be called,

Description of different qualities of food articles as per different Ayurvedic classics has been furnished in Table 2. 
Int. J. Ayur. Pharma Research, 2022;10(1):65-73

Table 2: Description of Different Qualities of food articles as per Different Ayurvedic Classics [20-23]

\begin{tabular}{|c|c|c|c|c|}
\hline Sl. No. & Charak Samhita & Susruta Samhita & Astanga Samgraha & Astanga Hridaya \\
\hline 1. & Suka Dhanya & Sali Varga & Sukadhanya Varga & Sukadhanya Varga \\
\hline 2. & Sami Dhanya & Sastika Varga & Simbidhnya Varga & Simbidhanya Varga \\
\hline 3. & Mamsa & Vrihi Varga & Kritanna Varga & Kritanna Varga \\
\hline 4. & Saka & Kudhanya Varga & $\begin{array}{l}\text { Mriga Mamsa Varga } \\
\text { (i) Viskira Varga } \\
\text { (ii) Pratuda Varga } \\
\text { (iii) Bilesaya Varga } \\
\text { (iv) Prasaha Varga }\end{array}$ & Mamsa Varga \\
\hline 5. & Phala & Mamsa Varga & $\begin{array}{l}\text { Mahamriga Varga } \\
\text { (i) Jalachara Varga } \\
\text { (ii) Matsya Varga }\end{array}$ & Saka Varga \\
\hline 6. & Harita & Phala Varga & Saka Varga & Phala Varga \\
\hline 7. & Madya & Saka Varga & Phala Varga & Ousadha Varga \\
\hline 8. & Jala & Puspa Varga & 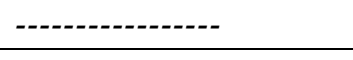 & 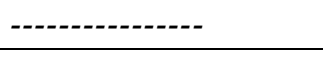 \\
\hline 9. & Gorasa & Kanda Varga & --------------- & 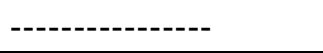 \\
\hline 10. & Ikshu Vikar & Lavan Varga & ----------------- & ---------------- \\
\hline 11. & Kritanna & Kritanna Varga & -------------- & ---------------- \\
\hline 12. & Aharayoni & Bhakshya Varga & ----------------- & ----------------- \\
\hline 13. & -------- & Anupana Varga & 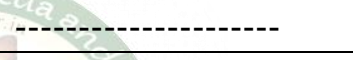 & ----------------- \\
\hline
\end{tabular}

\section{Right Method}

Proper approach of engaging the food may established in three fold concept as Samyoga, Samaskara, and Upayoga Vyabastha including Upachara.

Samyoga: Samyoga or admixture is the integration two or more materials together. This union produces special effects no longer present in individual materials of the aggregates. [9] Intake of sour substance with milk is known as Samyoga Viruddha and advised to avoid neither Madhu nor Ghrita causes death, but by their combination it may causes death. On the other hand fish and milk are not the causative agent for Kustha in their separate consumption but in combination results the manifestation. [24]

Samaskara: Samaskara or processing is the end result of contact with water and fire. Touch with water approaches soaking articles of food to make them moist and soft and make contact with of fire impacts the features of food. [9] Practice to take warm food provides proper taste and it initiates the Agni and helps to move the Vata with downwards following detachment of Kapha. ${ }^{[25]}$ Diets which when prepared in a way produce poisonous effects, for example meat of peacock roasted on a castor spit is known as Samaskara Viruddha and advised to avoid. [26]

\section{Upayoga Vyabastha including Upachara:} Considering the digestive capability and habituation, ingredients which might be either watery or Rukhsya, Madhura have to be consumed inside the beginning [9] with a sequence of fruits like Dadima, Peya etc. and solid food like boiled rice etc. to pacify the aggravated Vayu as result of excessive hunger. The ones which might be Amla and Lavan within the middle[9] as Amalaki and it increase the Agni [30] and those which can be dry (non- fatty) liquid and of different tastes like Tikta and Kasaya at the end [9] as Tambula and Amalaki to reduce the Pitta, as the Amalaki reduces the Pitta and increases the Agni therefore recommended at outset, middle and the close of a meal.[18. Those who have horrible digestive potential need to devour liquid and heat meals inside the beginning itself, for the digestive pastime getting inspired by the warmth, digest the other meals which can be eaten later, in a proper way [9]. Even is the food taken in the forenoon is not digested well, taking food once more within the night time does no longer motive any harm, while if the meals taken at night are not digested well, and taking food the following morning virtually causes damage. Food should not be partaken in very fast or very slow manner.[25] Food should be partaken following the symptoms of right digestion of meals as pure belching, (without any flavor or smell), enthusiasm, elimination of waste on the proper time, lightness of the body, look of the starvation and thirst. ${ }^{[12]}$ and proper consideration of Hita and Ahita as well Viruddha Ahara. Hita and Ahita and Viruddha Ahara are furnished in Table 3 and Table 4. 
Chiranjit Biswas, Supriyo Chaudhuri. Five Common Rights on Ayurvedic Dietetics

Table 3: Hita and Ahita Ahara Dravya[27]

\begin{tabular}{|c|l|l|l|}
\hline S. No. & Ahara Dravya & Hita Ahara Dravya & Ahita Ahara Dravya \\
\hline 1. & Sukadhanya & Shali & Yavaka \\
\hline 2. & Shami dhanya & Mudga & Masa \\
\hline 3. & Udaka & Rain Water & River Water \\
\hline 4. & Lavana & Saindhava & Ushra \\
\hline 5. & Shakha & Jivanti & Mustard Oil \\
\hline 6. & Mriga Mamsa & Ena & Gomamsa \\
\hline 7. & Meat of birds & Lava & Kapota Mamsa \\
\hline 8. & Vilesaya & Godha & Bheka \\
\hline 9. & Matsya & Rohita & Cilcima \\
\hline 10. & Sarpi & Goghrita & Avisarpi \\
\hline 11. & Milk & Godugdha & Avidugdha \\
\hline 12. & Sthawara Sneha & Tila Taila & Kusumbha Taila \\
\hline 13. & Anupamarga Vasa & Varaha vasa & Mahisa vasa \\
\hline 14. & Anupamrga vasa & Culuki vasa & Kumbhira vasa \\
\hline 15. & Matsya vasa & Pakahamsa vasa & Kakamadgu vasa \\
\hline 16. & Jalcara Vihanga vasa & Kukkuta Vasa & Chataka vasa \\
\hline 17. & Sakhada Meda & Aja fat & Fat of Hasti \\
\hline 18. & Kanda & Shringavera & Aluka \\
\hline 19. & Phala & Mridvika & Nikuca \\
\hline 20. & Iksu Vikara & Sharkara & Phanita \\
\hline & & Table & \\
\hline
\end{tabular}

Table 4: Different Types of Viruddha Ahara[28]

\begin{tabular}{|c|c|c|}
\hline 1 & Desha Viruddha & $\begin{array}{l}\text { Intake of dry and sharp substance in deserts; unctuous and cold substance in } \\
\text { marshy land }\end{array}$ \\
\hline 2. & Kala Viruddha & $\begin{array}{l}\text { Intake of cold and dry substance in winter; pungent and hot substance in the } \\
\text { summer }\end{array}$ \\
\hline 3. & Agni Viruddha & $\begin{array}{l}\text { Intake of Guru Dravya when the power of digestion is mild (Mandagni); intake of } \\
\text { Laghu, Dravya or light food when the Agni is Tikshna. }\end{array}$ \\
\hline 4. & Matra Viruddha & Intake of honey and ghee in equal quantity \\
\hline 5. & Satmya Viruddha & $\begin{array}{l}\text { Intake of sweet and cold substance by persons accustomed to pungent and hot } \\
\text { substance }\end{array}$ \\
\hline 6. & Dosa Viruddha & $\begin{array}{l}\text { Utilization of diets and regimen has similar qualities with Dosas but at variance } \\
\text { with the Satmya of the individual }\end{array}$ \\
\hline 7. & $\begin{array}{l}\text { Samskara } \\
\text { Viruddha }\end{array}$ & $\begin{array}{l}\text { Diets which when prepared in a way produce poisonous effects, for example meat } \\
\text { of peacock roasted on a castor spit }\end{array}$ \\
\hline 8. & Virya Viruddha & Substances have Sheeta Virya in combination with these of Ushna Virya \\
\hline 9. & Kostha Viruddha & $\begin{array}{l}\text { Administration of a mild purgative in a small dose for a person of Krura Koshtha } \\
\text { and administration of strong purgative in strong dose for a person having Mridu } \\
\text { Koshtha }\end{array}$ \\
\hline 10 & Avastha Viruddha & $\begin{array}{l}\text { Intake of Vata aggravating food by a person after exhaustion, sexual act and } \\
\text { physical exercise or intake of Kapha aggravating food by a person after sleep or } \\
\text { drowsiness }\end{array}$ \\
\hline 11. & Krama Viruddha & $\begin{array}{l}\text { If a person takes food before his bowel and urinary bladder is clear (empty) or } \\
\text { when he does not have appetite or after his hunger has been aggravated }\end{array}$ \\
\hline
\end{tabular}


Int. J. Ayur. Pharma Research, 2022;10(1):65-73

\begin{tabular}{|c|l|l|}
\hline 12. & $\begin{array}{l}\text { Parihara } \\
\text { Viruddha }\end{array}$ & Intake of hot thing after taking pork etc. and cold things after taking ghee \\
\hline 13. & $\begin{array}{l}\text { Upachara } \\
\text { Viruddha }\end{array}$ & Same as the above \\
\hline 14. & Paka Viruddha & $\begin{array}{l}\text { Preparation of food etc. with bad or rotten fuel and under cooking, over cooking or } \\
\text { burning during the process of preparation }\end{array}$ \\
\hline 15. & $\begin{array}{l}\text { Samyoga } \\
\text { Viruddha }\end{array}$ & Intake of sour substance with milk \\
\hline 16. & Hrudya Viruddha & Any substance which is not pleasant in taste \\
\hline 17. & $\begin{array}{l}\text { Sampada } \\
\text { Viruddha }\end{array}$ & Intake of substance that is not matured over matured or putrefied \\
\hline 18. & Vidhi Viruddha & Taking meal without follow the rules of eating \\
\hline
\end{tabular}

Nitya Prayukta Ahara or Susama Ahara: Ayurvedic text gives a guideline to take regularly take Swastika (a kind of rice harvested in sixty days), Sali (Oryza sativum Linn.), Mudga (Phaseolous mungo Linn.), rock salt, Amalaki (Emblica officinalis Gaertn.), Antarikshya Jala (rain water), ghee, meat of animals dwelling in arid climate and honey.[6]

\section{Drinks and Regimes after Taking Food}

Drinks: Water is the sustainer of life of all living beings. The entire world is full of it. Though the post prandial drinks have the opposite properties of the food partaken but it is not so harmful to the Dhatu of the body ${ }^{[29]}$ and it produces the soothing effect. ${ }^{[4]}$ After completion of meal water should be drunk in quantity which would be beneficial for healthy life.[30] According Dosika configuration of body as well as disease; Snigdha and Ushna Jala is indicated in Vata, Madhur and Sital Jala for Pitta and Rukshya and Ushna Jala for Kapha. [29] Warm water is also ideal after taking food which are from Saka Mudgadi Vikriti, Mastu, Takra and as Anupana cold water is ideal.[29] Obese person should take water just before the meal as it causes emaciation and weakness of digestion, emaciated person should take water at the end of meal as it causes obesity and accumulation of Kapha in the upper part of stomach and normal person is advised to take water in the middle of meal as it promotes Dhatu Samya. [31] It is best to avoid drinking large amount of water as it causes incensement of Kapha and Pitta.
Regimens: Vayu is increased after the completion of digestion Pitta, during the continuance of the digestion process and Kapha, immediately after the act of eating So Kapha is to be subdued after the close of a meal Attain that end by partaking fruits of a Kasaya, Katu, Tikta or Tambula Sevan Chewing a betel leaf with Puga- broken areca nut Kankola- nutmeg Karpuracamphor Lavanga- clove Sumanah phala- Rest like a king till the sense of Yabadanna kloma (drowsiness incidental to eating) is removed Walking a hundred place - Padashatam Gatwa Lie down in a bed on his left side Sabda Rupa Rasan Gandhan Sparshascha Manasa Priyana. ${ }^{32]}$

\section{Right Place}

The right place of Ahara includes Mahanas or Kitchen, Bhojan Patra or Utensils and proper consideration Satmya according to Desha.

Mahanas or Kitchen: Mahanas should be spacious and kept clean and pure and only trusted ones termed as Suda should have access experienced cooks the tasty and delicious food with proper colour and odour. It must be clean and pure spot free from all poison by reciting mantra and sprinkled with the water of mystic incantation.

Bhojan Patra: For the purpose of serving food different types of Bhojan Patra or utensils has been described by different classics ${ }^{[33],[9]}$ in Table- $V$

Table 5: Bhojan Patra and Their Utility by Different Classics

\begin{tabular}{|c|l|l|l|}
\hline S.No. & Bhojan Patra & Susruta Samhita & Astanga Samgraha \\
\hline 1. & Silver vessel & Peya, Yusha, Rasa (Mutton Soup) & Peya, Yusha, Rasa (Mutton Soup) \\
\hline 2. & Gold vessel & Parisushka \& Paridagdha Mamsa & Ruksha, Ushna Ahara, Dugdha \\
\hline 3. & Bronze vessel & Kkala, Khatwava, Kambalika \\
\hline 4. & Vaidurjya or crystal vessel or glass & Raga Sadava \& Sattaka & Raga Sadava \& Sattaka \\
\hline 5. & Mud, gold or glass vessel & Other drinks, Madya etc. & $\begin{array}{l}\text { Drinking water, syrups, boiled } \\
\text { rice }\end{array}$ \\
\hline 6. & Iron vessel & Clarified butter & Ghee \\
\hline 7. & Cupper vessel & Cooked milk & Cooked milk \\
\hline \hline
\end{tabular}




\begin{tabular}{|c|l|l|l|}
\hline 8. & Leaves & Fruits \& confectionary & - \\
\hline 9. & Stone vessel & Katu Rasa \& Kshara & - \\
\hline
\end{tabular}

And further, different kinds of food designed on the dining table as Bhaksya or eatables are to be arranged on the right side, Peya (drinkables) Lehya (lickables) and balls which require hard chewing is to be on the left side and Bhojya or staple or the chief food in the Centre. [9]

Desha: Depending upon the Auchitya or habitat or Desha the Pathya or wholesome food becomes unwholesome resulting unhappiness. To maintain the happiness the food is to be considered with the particular Desha according to Satmya. Mamsa, Godhuma, Madhvika is habituated in Bhalmika, Shadbal, China, Shulika, Yavana and Shaka Desha; Matsya is habituated in Prachya Desha or eastern part of India, Dugdha in Sindhu Desha, Taila and Amla in Asmaka and Abanti Desha, Kanda, Mula and Phala in Malaya Desha, Peya in Dakshinatya Desha, Manda in Paschim-Uttara Desha, Yava, Godhuma and Gorasa is habituated in Madhya Desha. [34]

\section{DISCUSSION}

Panoramic description has been given in context of Ahara by several Ayurvedic literatures as life is unfeasible devoid of Ahara and intimated with Bramha. ${ }^{[35]}$ in other words Ahara promotes strength, complexion, vital essence, growth and development, functioning of sense faculties, happiness, clarity of voice, luster, pleasure, increase of Dhatus, intellect, health etc. With due consideration of Hita- Ahita Ahara as Ekanta-Hita or the food which is not harmful to the body even though used always like water, milk, ghee and Oudana, Ekanta-Ahita, which causes maltreat the body quickly and so cannot be used even for short period, which are always unsuitable and cause Dahana, Pachana and Marana like Kshara and Visha and Hita Ahita, which do not harm in certain conditions but cause harm in certain other conditions. ${ }^{[36]}$ Another concept of Hita-Ahita in context to Ahara as participating meals in immoderate amount is the reasons of Amaprodosha. Consumption of meals consistent with power of digestion promotes the Agni, continually practicing the healthy diets and regimes comply with the version of excellent regimes. Participating of food in proper time offers Arogya. Right nice of meals gives Tripti. A heavy meal reasons the Durbipaka. Praghata or slaughtering vicinity causes Asroddhajananam to the food. Continuous fasting causes the Ayuhrasha. Engaging of food in very small amount reasons Karshya, intake of food earlier than the previous meal is digested reasons Grahani Dosha, consumption of abnormal meal causes Agnibaishamya, consumption of food having together contradictory properties reasons Ninditavyadhi. Pathya reasons the feelings of reposefulness after taking meals. Objectivity causes the Pusti. Normal intake of all taste meals promotes Bala. Everyday intake of food having best one taste reasons Daurbalya. [4] In the present study improper implementation of "five common Rights" results in alteration of Agni, leads to propagation of Ama in the body. This Ama is the fundamental cause of various diseases categorized as Amaprodosaja Vikara. Visuchika and Alasaka caries their extremity with Dandalasaka and followed by the production of Amavisha. [20] Apart from that, Ajirna[37] has been introduced from the mal implementation of these common rights. Amajirna is produced due to increase of Kapha; Vistabdhajirna is from increased Vayu and Vidagdhajirna due to increase of Pitta. Further accumulation of more and more Amadosha causes Vilambika and trends to Rasaseshajirna. In this extreme condition day sleep is indicated devoid of any food.[15] On the other hand Santarpanajanya Vyadhi and Apatarpanajanya Vyadhi has the reference due to over nourishment and less nourishment respectively. Prameha, Pidaka, Kotha, Kandu, Pandu, Sthaulya, Mutrakriccha etc. are categorized under the disease due to over nourishment and Karshya, Oja Kshya, Sukra Kshya, Unmada, Urdhavata etc. are included under the Apatarpanajanya Vyadhi.[38] Handiest the character having a wholesome body can afford to carry out all activities main to happiness, heaven and salvation and for the upkeep of fitness consumption of meals is essential. Consequently a meal is the basic factor for the attainment of them all and should be taken cautiously following the Right Quantity Right Time, Right Quality, Right Method, and Right Place.

\section{CONCLUSION}

Consideration of five common rights in context to Ahara is an important era of present dietary habits. Dietary measures have been included in Troyoupasthambha in a precious manner to enumerate the human pursuit. This can promote proper Swasthya and stands with Jitendriya. Misinterpretation may lead to many diseases which come unwillingly to a person. Therefore, is very important to maintain the Dosha Samya, Dhatu Samya, Mala Samya as well as Agni Samya, which carries out the aim and object of Ayurveda. Primarily right quantity of food should be adopted to sustain the healthy life and discouraging the rules causes Amaprodosha. Right time of food provide the disease free life. Right quality of food provides the strength. Right method of partaking the food provides self-preservation and right place for taking food providing respect to the food consumed. For the sake of these benefits, in the present study the common rights of Ayurvedic dietetics has been stapled in the above sequence. 


\section{REFERENCES}

1. Sir-Raja-Radhakantadeva-Bahadura, Shabda kalpadruma, 2nd ed. Pratham Khanda, Swarabarna, Delhi: Nag Publishers; 2003; p.166.

2. Prof.Srikantha Murthy, Astanga Samgraha of Vagbhata, Sutra Sthan. 2nd ed. Vol.-I. Ch. 9, Ver. 111. Varanasi: Chaukhamba Orientalia; 1998; p.224.

3. R.K. Sharma, Bhagawan Das, Carak Samhita of Agnivesha, Sutra Sthan. $6^{\text {th }}$ ed. Vol.-I. Ch. 28., Ver. 45. Varanasi: Chowkhamba Sanskrit Series Office; 2000; p. 583.

4. R.K.Sharma, Bhagawan Das, Carak Samhita of Agnivesha, Sutra Sthan. $6^{\text {th }}$ ed. Vol.-I. Ch. 25., Ver. 40. Varanasi: Chowkhamba Sanskrit Series Office; 2000; p. 427.

5. Prof.P.V.Tewari, Kasyapa Samhita or Vriddhajivakiya Tantra, Khila Sthan. 1st ed. Ch.4, Ver.5. Varanasi: Chaukhamba Visvabharati; 1996; p. 468.

6. Vaidya Jadavji Trikamji Acharya, editor. Chakrapanidutta, commentator, Caraka Samhita of Agnivesha, Sutra Sthan. 1 st $^{\text {ed. Ch.5. Ver.5-8. }}$ Varanasi: Chaukhambha Orientalia; 2004. p. 37-38.

7. R.K.Sharma, Bhagawan Das, Carak Samhita of Agnivesha, Viman Sthan. 6th ed. Vol.-II. Ch. 2, Ver. 3. Varanasi: Chowkhamba Sanskrit Series Office; 2000; p. 132.

8. Dr.Jyotir Mitra, Susruta Samhita by Kaviraj Kunjalal Bhishagratna, 1st ed. Vol.-I, Ch.46, Ver. 471-474, Varanasi: Chowkhamba Sanskrit Series Office; 1998. p.537.

9. Prof.Srikantha Murthy, Astanga Samgraha of Vagbhata, Sutra Sthan. 2nd ed. Vol.-I. Ch.10, Ver. 9. Varanasi: Chaukhamba Orientalia; 1998; p.234.

10. Vaidya Jadavji Trikamji Acharya, editor. Chakrapanidutta, commentator, Caraka Samhita of Agnivesha, Viman Sthan. 1st ed. Ch.1. Ver.6. Varanasi: Chaukhambha Orientalia; 2004. p. 37231.

11. R.K.Sharma, Bhagawan Das, Carak Samhita of Agnivesha, Sutra Sthan. 6 ${ }^{\text {th }}$ ed. Vol.-I. Ch. 6, Ver. 448. Varanasi: Chowkhamba Sanskrit Series Office; 2000; p. 130-142.

12. Prof.Srikantha Murthy, Astanga Samgraha of Vagbhata, Sutra Sthan. 2nd ed. Vol.-I. Ch.11, Ver. 3637. Varanasi: Chaukhamba Orientalia; 1998; p.255.

13. Dr.Jyotir Mitra, Susruta Samhita by Kaviraj Kunjalal Bhishagratna, $1^{\text {st }}$ ed.Vol.-I, Ch. 46, Ver. 468-470, Varanasi: Chowkhamba Sanskrit Series Office; 1998. p.536.

14. Prof.K.R. Srikanta Murthy, Sarangadhar Samhita, $3^{\text {rd }}$ ed. Pratham Kahanda, Ch.2, Ver.29. Varanasi: Chaukhambha Orientalia; 1997. p.13.
15. Prof.K.R. Srikanta Murthy, Vagbhata's Astanga Hridayam, Sutra Sthan. $5^{\text {th }}$ ed. Vol.-I, Ch.3, Ver. 58591/2. Varanasi: Krishnadas Academy; 2003; p.44.

16. Prof.Srikantha Murthy, Astanga Samgraha of Vagbhata, Sutra Sthan. 2nd ed. Vol.-I. Ch.4, Ver. 61611/2. Varanasi: Chaukhamba Orientalia; 1998; p.68.

17. Vaidya Jadavji Trikamji Acharya, editor. Chakrapanidutta, commentator, Caraka Samhita of Agnivesha, Viman Sthan. 1 ${ }^{\text {st }}$ ed. Ch.2. Ver.10-15. Varanasi: Chaukhambha Orientalia; 2004. p. 37240.

18. Dr.Jyotir Mitra, Susruta Samhita by Kaviraj Kunjalal Bhishagratna, $1^{\text {st }}$ ed. Vol.-I, Ch.46, Ver. 459, Varanasi: Chowkhamba Sanskrit Series Office; 1998. p.534.

19. Dr.Laxmidhar Dwivedi, Susruta Samhita by Kaviraj Kunjalal Bhishagratna, 1st ed. Vol.-I, Ch.64, Ver. 55, Varanasi: Chowkhamba Sanskrit Series Office; 1999. p.627.

20. R.K.Sharma, Bhagawan Das, Carak Samhita of Agnivesha, Sutra Sthan. $6^{\text {th }}$ ed. Vol.-I. Ch. 27, Ver. 57. Varanasi: Chowkhamba Sanskrit Series Office; 2000 ; p. 493.

21. Dr.Laxmidhar Dwivedi, Susruta Samhita by Kaviraj Kunjalal Bhishagratna, $1^{\text {st }}$ ed. Vol.-I, Ch.46, Varanasi: Chowkhamba Sanskrit Series Office; 1999. p.449.

22. Prof. Srikantha Murthy, Astanga Samgraha of Vagbhata, Sutra Sthan. 2nd ed. Vol.-I. Ch.7, Varanasi: Chaukhamba Orientalia; 1998; p.115.

23. Prof.K.R.Srikanta Murthy, Vagbhata's Astanga Hridayam, Sutra Sthan. 5th ed. Vol.-I, Ch.6, Varanasi: Krishnadas Academy; 2003; p.76.

24. Vaidya Jadavji Trikamji Acharya, editor. Chakrapanidutta, commentator, Caraka Samhita of Agnivesha, Viman Sthan. $1^{\text {st }}$ ed. Ch.1. Ver.3. Varanasi: Chaukhambha Orientalia; 2004. p. 37-23.

25. Vaidya Jadavji Trikamji Acharya, editor. Chakrapanidutta, commentator, Caraka Samhita of Agnivesha, Viman Sthan. 1 ${ }^{\text {st }}$ ed. Ch.1. Ver.25. Varanasi: Chaukhambha Orientalia; 2004. p. 267.

26. Vaidya Jadavji Trikamji Acharya, editor. Chakrapanidutta, commentator, Caraka Samhita of Agnivesha, Sutra Sthan. 1st ed. Ch.26. Ver.92. Varanasi:Chaukhambha Orientalia; 2004. p.151.

27. R.K.Sharma, Bhagawan Das, Carak Samhita of Agnivesha, Sutra Sthan. 6th ed. Vol.-I. Ch. 25., Ver. 39. Varanasi: Chowkhamba Sanskrit Series Office; 2000; p. 424.

28. R.K.Sharma, Bhagawan Das, Carak Samhita of Agnivesha, Sutra Sthan. $6^{\text {th }}$ ed. Vol.-I. Ch. 26, Ver. 86-101. Varanasi: Chowkhamba Sanskrit Series Office; 2000; p. 485-486. 
29. R.K.Sharma, Bhagawan Das, Carak Samhita of Agnivesha, Sutra Sthan. $6^{\text {th }}$ ed. Vol.-I. Ch. 27, Ver. 319. Varanasi: Chowkhamba Sanskrit Series Office; 2000; p. 557.

30. Dr.Jyotir Mitra, Susruta Samhita by Kaviraj Kunjalal Bhishagratna, $1^{\text {st }}$ ed.Vol.-I, Ch.46, Ver. 487, Varanasi: Chowkhamba Sanskrit Series Office; 1998. p.539.

31. Prof.Srikantha Murthy, Astanga Samgraha of Vagbhata, Sutra Sthan. $2^{\text {nd }}$ ed. Vol.-I. Ch.6, Ver. 4041. Varanasi: Chaukhamba Orientalia; 1998; p.90.

32. Dr.Jyotir Mitra, Susruta Samhita by Kaviraj Kunjalal Bhishagratna, $1^{\text {st }}$ ed. Vol.-I, Ch.46, Ver. 493, Varanasi: Chowkhamba Sanskrit Series Office; 1998. p.540.

33. Dr.Jyotir Mitra, Susruta Samhita by Kaviraj Kunjalal Bhishagratna, $1^{\text {st }}$ ed. Vol.-I, Ch.46, Ver. 455-463, Varanasi: Chowkhamba Sanskrit Series Office; 1998. p.534.
34. Vaidya Jadavji Trikamji Acharya, editor. Chakrapanidutta, commentator, Caraka Samhita of Agnivesha, Chikitsa Sthan. $1^{\text {st }}$ ed. Ch.30. Ver. 315320. Varanasi: Chaukhambha Orientalia; 2004. p. 648.

35. Dr.Jyotir Mitra, Susruta Samhita by Kaviraj Kunjalal Bhishagratna, $1^{\text {st }}$ ed. Vol.-I, Ch.46, Ver. 2, Varanasi: Chowkhamba Sanskrit Series Office; 1998. p.448.

36. Dr.Jyotir Mitra, Susruta Samhita by Kaviraj Kunjalal Bhishagratna, 1st ed. Vol.-I, Ch.20, Ver. 7, Varanasi: Chowkhamba Sanskrit Series Office; 1998. p.176.

37. Vaidya Jadavji Trikamji Acharya, editor. Chakrapanidutta, commentator, Caraka Samhita of Agnivesha, Chikitsa Sthan. $1^{\text {st }}$ ed. Ch.30. Ver. 315320. Varanasi: Chaukhambha Orientalia; 2004. p. 517.

38. Vaidya Jadavji Trikamji Acharya, editor. Chakrapanidutta, commentator, Caraka Samhita of Agnivesha, Sutra Sthan. $1^{\text {st }}$ ed. Ch.23. Ver. 5-39. Varanasi: Chaukhambha Orientalia; 2004. p. 122124.
Cite this article as:

Chiranjit Biswas, Supriyo Chaudhuri. Five Common Rights on Ayurvedic Dietetics - A Review. International Journal of Ayurveda and Pharma Research. 2022;10(1):65-73.

https://doi.org/10.47070/ijapr.v10i1.2193

Source of support: Nil, Conflict of interest: None Declared
*Address for correspondence Dr. Chiranjit Biswas

Lecturer,

Department of Sanskrit Samhita

\& Siddhanta

J.B. Roy State Ayurvedic Medical College \& Hospital, 170-172 Raja

Dinendra Street, Kolkata.

Email: biswaschiranjit33@gmail.com

Disclaimer: IJAPR is solely owned by Mahadev Publications - dedicated to publish quality research, while every effort has been taken to verify the accuracy of the content published in our Journal. IJAPR cannot accept any responsibility or liability for the articles content which are published. The views expressed in articles by our contributing authors are not necessarily those of IJAPR editor or editorial board members. 